\title{
OPEN ACCESS - NOWY MODEL DOSTĘPU DO WYNIKÓW BADAŃ NAUKOWYCH
}

\author{
Anna Wałek \\ Biblioteka Główna \\ Politechniki Wrocławskiej
}

Open Access, badania naukowe, prawa autorskie, cyfrowe repozytoria

Idea Open Access (OA) to swobodne i nieograniczone udostępnianie publikacji naukowych w Internecie. Autorzy i właściciele praw autorskich dają użytkownikom Internetu darmowe, nieodwołalne, szerokie, trwałe prawo dostępu do dzieła i licencję na kopiowanie, użycie i dalsze niekomercyjne rozpowszechnianie dzieła oraz prawo do tworzenia i rozpowszechniania prac pochodnych z zachowaniem atrybucji autorskich ${ }^{1}$. Nie oznacza to jednak, że literatura udostępniana w ramach OA nie jest chroniona prawem autorskim i odpowiednimi licencjami. Sa to zwykle licencje typu copyleft ${ }^{2}$, np. Creative Commons (licencje typu „pewne prawa zastrzeżone”), które powstały jako alternatywa dla restrykcyjnego prawa autorskiego. Czytelnika obowiązuje oczywiście zachowanie integralności publikacji, poszanowanie prawa do własności intelektualnej - zachowanie autorstwa i obowiązek cytowania. Autor zachowuje prawo do dysponowania własnością intelektualna, może też określać pola eksploatacji, jak również ten sam utwór opublikować komercyjnie ${ }^{3}$.

Open Access Movement to nazwa całego ruchu społecznego, którego celem jest zminimalizowanie przeszkód w upowszechnianiu wyników badań naukowych, a także bardziej efektywne wykorzystywanie nakładów na naukę. Zwolennicy OA podkreślają potrzebę szybkiego i powszechnego dostępu do wyników badań naukowych, zwłaszcza tych, które finansowane są ze środków publicznych. Od dawna bowiem pojawiaja się głosy krytykujące fakt, że podatnik najpierw finansuje badania naukowe, a następnie musi płacić za dostęp do ich wyników. Ruch ten jest reakcją na rosnące ceny prenumeraty czasopism

\footnotetext{
${ }^{1}$ Według definicji zapisanej w Bethesda Statement on Open Access Publishing i Deklaracji Berlińskiej.

${ }^{2}$ Rodzaj systemu licencjonowania praw autorskich, zezwalający na modyfikację i dowolną redystrybucję dzieła. Nazwa etymologicznie jest odwróceniem znaczenia słowa copyright i jednocześnie swoistą grą słowna. . "Copy" (kopiowanie) i "right" (prawo) to inaczej zastrzeżenie wszelkich praw do kopiowania, natomiast "left" to po angielsku „lewo" i jednocześnie forma czasownika „leave" (porzucić), zatem termin „copyleft” może być rozumiany jako świadome „porzucenie" zastrzeżeń do kopiowania.

${ }^{3}$ Przykładem utworu, który pierwotnie powstał w wersji elektronicznej, a następnie doczekał się drukowanego wydania, może być książka Wolna Kultura Lawrence'a Lessinga, która w wielu krajach cieszy się ogromną popularnością i której nakłady, pomimo dostępności w Internecie, rozeszły się w bardzo szybkim tempie.
} 
i znaczne koszty dostępu do ich wersji elektronicznych. Jest również odpowiedzią środowisk naukowych na długotrwały proces wydawniczy, długi okres oczekiwania na recenzje, limity przyjmowanych do publikacji prac oraz wysokie ceny prenumeraty powodujące zmniejszenie liczby odbiorców i tym samym spadek cytowań prac naukowych ${ }^{4}$.

Proces upowszechniania wyników badań naukowych do lat siedemdziesiątych XX w. przebiegał, w uproszczeniu mówiąc, na zasadzie wymiany myśli pomiędzy naukowcami na łamach drukowanych czasopism naukowych. Już wówczas jednak wyniki badań naukowych zaczęły być postrzegane jako produkty mające wartość rynkową. Prywatni przedsiębiorcy zaczęli nabywać prawa do wydawania czasopism od towarzystw naukowych i instytucji. Wraz ze wzrostem liczby placówek naukowych wzrastała liczba pracowników oraz efektów ich pracy w postaci książek i artykułów w periodykach czy materiałach konferencyjnych. To wszystko spowodowało wzrost produkcji wydawniczej, zwłaszcza w obszarze czasopism naukowych. Ceny periodyków rosły w szybkim tempie, osiagajac poziom ponad $220 \%$ wzrostu w latach $1986-2002^{5}$. Budżety bibliotek pozostawały ograniczone, co spowodowało tzw. kryzys czasopiśmienniczy. Bibliotekarze często rezygnowali z subskrypcji lub przerzucali środki na zakup czasopism z puli przeznaczonej na zakup książek. Kryzys ten stał się podstawą utworzenia wielu ruchów walczących ze wzrostem cen czasopism naukowych i baz danych. Jednym z silniejszych stał się ruch Open Access, którego celem jest doprowadzenie do otwarcia elektronicznych archiwów, bardziej ekonomiczne wydawanie prac naukowych i swobodne udostępnianie ich w Internecie.

Podstawowym impulsem do rozwoju ruchu Open Access było powstanie Internetu, który mógł być wykorzystywany jako kanał dystrybucji tekstów naukowych. Jednocześnie dynamiczny rozwój nauki oraz pojawienie się nowych technologii ujawniły potrzebę stworzenia szybszego, sprawniejszego i łatwo dostępnego systemu publikowania wyników badań naukowych.

Tradycja Open Access wywodzi się z budowania pierwszych na świecie otwartych archiwów elektronicznych dokumentów (tzw. e-printów), zwanych Open Archives. Open Archives Initiative (OAI) pojawiła się w USA w 1999 r. Propaguje ideę wolnego dostępu do informacji jako szansę dla współczesnego świata i jego cywilizacyjnego rozwoju. Internet bowiem, z założenia, ma zapewniać poczucie wolności i współdecydowania o dostępie do wiedzy wszystkim, bez względu na miejsce zamieszkania i zasoby finansowe.

Inicjatywa związana z ruchem Open Archives sięga lat sześćdziesiątych $X X$ w., kiedy w USA powstały centra informacji edukacyjnej ERIC i MEDLINE. Otwarte archiwa miały za zadanie przyspieszyć przepływ informacji, zwłaszcza w naukach ścisłych. Głównym założeniem tej inicjatywy był wolny, bezpłatny i przede wszystkim szybki dostęp do wiedzy. Otwarte archiwa zaczęły się dynamicznie rozwijać początkowo w USA i Europie Zachodniej. Kontynuacją Open Archives jest współcześnie inicjatywa, którą oficjalnie nazywa się właśnie Open

${ }^{4}$ Niedźwiedzka B.: Open Access cz. 1. „Forum Akademickie” 2005, nr 4. [online]. [dostęp: 10.09.2009]. Dostępny w World Wide Web: <http://forumakad.pl/archiwum/2005/04/ 17-za-open_acces_cz_1.htm>.

${ }^{5}$ Kaczmarek E., Rychlik M.: Czy repozytoria będą wspierać naukę w Polsce? „Logistyka" 2007, nr 4, s. 93-97. 
Access $^{6}$. Bardzo ważnym wydarzeniem dla rozwoju OA było pojawienie się na początku lat dziewięćdziesiątych wolnych, elektronicznych, recenzowanych czasopism naukowych. Były to m.in. takie tytuły jak: „Psycoloquy”, „Electronic Journal of Communication”, „Postmodern Culture”, „Bryn Mawr Classical Review”, które pojawiły się już w 1990 roku. Ich powstanie i udane funkcjonowanie pokazało światu, że można inaczej, taniej i zgodnie ze standardami istnieć w świecie nauki. Szacuje się, że obecnie w otwartym dostępie funkcjonuje ok. 5000 tytutów recenzowanych czasopism naukowych, a 10-15\% wszystkich recenzowanych rocznie artykułów ukazuje się w formie Open Access ${ }^{7}$.

Udostępnianie prac naukowych w wolnym dostępie przybiera trzy zasadnicze formy. Sa to bezpłatnie dostępne elektroniczne wersje recenzowanych czasopism naukowych, mających swoją wersję drukowana, czasopisma wydawane wyłącznie w wersji elektronicznej oraz bezpłatnie dostępne archiwa instytucjonalne, dziedzinowe lub indywidualne.

Publikowanie wyłącznie w wersji elektronicznej nazywamy Open Access Publishing (OAP), natomiast umieszczanie dokumentu w powszechnie dostępnym repozytorium lub na stronie internetowej - Open Access Archiving (OAA). Otwarty sposób archiwizowania może dotyczyć wszelkiego rodzaju opracowań: przed publikacją i po publikacji (czyli preprintów i postprintów) lub materiałów w ogóle nieprzeznaczonych do oficjalnego obiegu. Problematyka ta dotyczy nie tylko prac recenzowanych, ale również wszelkich innych prac naukowych. Mogą to być raporty z badań, rozprawy doktorskie, wystapienia konferencyjne, materiały szkoleniowe oraz inne tego typu dokumenty, których w każdej instytucji i bibliotece jest wiele, a które stanowią tzw. szarą literaturę.

Jak już wspomniano, w $1990 \mathrm{r}$. i w latach następnych powstało wiele czasopism recenzowanych w ramach inicjatywy Open Access. W 1991 r. powstało pierwsze internetowe archiwum udostępniające w wolnym dostępie recenzowane publikacje z zakresu fizyki-ArXiv ${ }^{8}$. Jego twórca, Paul Ginsparg, miał na celu udostępnienie serwisu, za pomocą którego fizycy mogliby dzielić się między soba wynikami swoich badań. Początkowo był to serwis oparty na komunikacji e-mailowej, jednak sukcesywnie przeniósł się do środowiska sieciowego. Nawet dziś wielu fizyków umieszcza w nim preprinty swoich prac przed wysłaniem ich do wydawcy ${ }^{9}$. W 1997 r. powstało archiwum publikacji o nazwie CogPrints ${ }^{10}, z$ takich dziedzin jak psychologia, lingwistyka, neurologia i informatyka, udostępniające ponad 2000 obiektów cyfrowych ${ }^{11}$. W ostatnich latach liczba repozytoriów, czasopism OA oraz publikacji dostępnych w ramach wolnego dostępu stale i dynamicznie wzrasta.

\footnotetext{
${ }^{6}$ Bednarek-Michalska B.: Wolny dostęp do informacji i wiedzy czy wykluczenie edukacyjne? Trendy światowe a Polska. „Biuletyn EBIB” 2005, nr 2 (63) luty [online]. [dostęp: 10.09.2009]. Dostępny w World Wide Web: <http://ebib.oss.wroc. pl/2005/63/michalska. php>.

${ }^{7}$ Źródło: DOAJ - Directory of Open Access Journals. [online]. [dostęp: 10.09.2009]. Dostępny w World Wide Web: <http://www.doaj.org/>

${ }^{8}$ Adres projektu: <http://arxiv.org/>

${ }^{9}$ Open Access: Profile of Eberhard Hilf. [w:] Open and shut? Blog of Richard Poynder. [online]. [dostęp: 10.10.2009]. Dostępny w World Wide Web: <http://poynder.blogspot. com>.

${ }^{10}$ Adres projektu: <http://cogprints.org/>

"Niedźwiedzka B., op. cit.
} 
W Polsce OA nie rozwija się zbyt dynamicznie, ale w otwartym dostępie możemy dziś znaleźć wiele czasopism naukowych i wydawnictw uczelnianych. $Z$ doświadczenia Dolnośląskiej Biblioteki Cyfrowej (DBC) oraz innych bibliotek cyfrowych w pozyskiwaniu licencji od autorów wciąż widać ograniczone zaufanie do publikowania w ramach otwartych repozytoriów. W Polsce brak jeszcze dużych repozytoriów OA na wzór amerykańskiego eScholarship ${ }^{12}$ czy szkockiego ERA Edinburgh Reseasch Archive ${ }^{13}$, jednak funkcje takie pełnią właśnie biblioteki cyfrowe, których już ponad 50 funkcjonuje w ogólnopolskiej sieci PIONIER ${ }^{14}$. Funkcję taką mają pełnić również projekt DIR - Domena Internetowych Repozytoriów Wiedzy ${ }^{15}$, tworzony przez Interdyscyplinarne Centrum Modelowania Matematycznego Uniwersytetu Warszawskiego (ICM), który jest kontynuacją Biblioteki Wirtualnej Nauki oraz projekty instytucjonalne. W marcu 2010 r. Uniwersytet im. A. Mickiewicza w Poznaniu (UAM) uruchomil otwarte repozytorium instytucjonalne AMUR ${ }^{16}$ (Adam Mickiewicz University Repository). Wśród prezentowanych w nim zasobów znalazły się czasopisma, prace naukowe i badawcze, materiały konferencyjne i dydaktyczne, a także rozprawy doktorskie, które przekazywane są do repozytorium na podstawie zarządzenia rektora UAM. Zarządzenie ${ }^{17}$ z 20 listopada 2009 r. jest pierwszym w Polsce aktem nakazujacym deponowanie doktoratów w repozytorium instytucjonalnym. Do tej pory podobne zarządzenia zwykle pozostawiały autorom decyzję w zakresie udzielenia uczelni odpowiedniej licencji. W lutym 2010 r. w rejestrze mandatów Open Access - Registry of Open Access Repository Material Archiving Policies (ROARMAP) ${ }^{18}$ zarejestrowany został pierwszy wpis pochodzący z Polski. Jest to rozporządzenie obowiazzujące w Instytucie Biochemii i Biofizyki PAN w Warszawie, dotyczące obowiązku archiwizowania w repozytorium instytucjonalnym IBB PAN wszystkich opublikowanych prac naukowych ${ }^{19}$

Chociaż z przeprowadzonych w wielu ośrodkach badań wynika, że powszechny dostęp do spuścizny naukowej nie tylko sprawia, że nazwisko autora jest powszechniej znane, lepiej indeksowane przez internetowe wyszukiwarki,

${ }^{12}$ Adres projektu: <http://repositories.cdlib.org/escholarship>

${ }^{13}$ Adres projektu: <http://www.era.lib.ed.ac.uk/index.jsp>.

${ }^{14}$ Sieć PIONIER obejmuje ponad 51 instytucjonalnych i regionalnych bibliotek cyfrowych. Dostęp do ich zasobów ułatwiony jest za pomocą multiwyszukiwarki zasobów cyfrowych Federacja Bibliotek Cyfrowych.

${ }^{15}$ Adres projektu: <http://dir.icm.edu.pl>

${ }^{16}$ Adres projektu: <https://repozytorium.amu.edu.pl/jspui/>

17 Zarzadzenie nr 110/2009/2010 rektora Uniwersytetu im. A. Mickiewicza w Poznaniu z dnia 20 listopada 2009 r. w sprawie gromadzenia i udostępniania przez Bibliotekę Uniwersytecką $w$ repozytorium AMUR rozpraw doktorskich bronionych na Uniwersytecie im. A. Mickiewicza w Poznaniu [online], [dostęp: 16.05.2010]. Dostępny w World Wide Web: <http://pracownicy. amu.edu.pl/tresci/dokumenty-uam/data/zarzdzenia-rektora-uam/zarzdzenia-z-roku-2009/zarzdzenie-nr-11020092010-rektora-uam-z-dnia-20-listopada-2009-roku-w-sprawie-gromadzenia-iudostpniania-przez-bibliotek-uniwersyteck-w-repozytorium-amur-rozpraw-doktorskich-bronionych-na-uniwersytecie-im.-adama-mickiewicza-w-poznaniu>.

${ }^{18}$ Adres projektu: <http://www.eprints.org/openaccess/policysignup/>.

${ }^{19}$ OA Self-Archiving Policy: Institute of Biochemistry and Biophysics Polish Academy of Sciences [online], [dostęp: 16.05.2010]. Dostępny w World Wide Web: <http://www. eprints.org/openaccess/policysignup/fullinfo. php?inst=Institute $\% 20$ of $\% 20 \mathrm{Biochemi-}$ stry $\% 20$ and $\% 20$ Biophysics $\% 20$ Polish $\% 20$ Academy $\% 20$ of $\% 20$ Sciences>. 
ale również wpływa na zwiększenie cytowalności zarówno określonego dzieła, jak i całej twórczości autora, wciąż niewielu autorów decyduje się na udostępnianie własnej twórczości w wolnym dostępie. Na przykład, publikacje naukowe wydawane przez Oficynę Wydawnicza Politechniki Wrocławskiej ukazują się w stosunkowo niskich nakładach, ale dzięki upowszechnieniu w DBC trafiają do większego grona odbiorców, a równocześnie nakład jest w całości sprzedawany. Poza niektórymi publikacjami naukowymi, wydawanymi przez Oficynę Wydawniczą PWr i wydawnictwa innych uczelni należących do Konsorcjum DBC, do zbiorów Dolnośląskiej Biblioteki Cyfrowej, na podstawie umów z wydawcą trafiają również bieżące czasopisma naukowe takie jak: „Wiadomości Chemiczne”, "Materials Science : an International Journal of Physics, Chemistry and Technology of Materials”, „Advances in Clinical and Experimental Medicine”, „Dental and Medical Problems”, „Polimery w Medycynie”, „Argumenta Oeconomica”, a także rozprawy doktorskie i habilitacyjne pracowników dolnośląskich uczelni. Wciaż jednak jest to zbyt mało w porównaniu z repozytoriami zagranicznymi, gdzie idea OA jest lepiej rozumiana i szerzej wspierana zarówno przez państwo, jak i środowiska naukowe. Ruch OA wymaga społecznych działań nie tylko w sferze samego publikowania i aktywności autorów. Aby móc konkurować z tradycyjnymi kanałami przepływu informacji naukowej, niezbędna jest również działalność recenzentów, a także społecznie tworzone repozytoria, serwisy i oprogramowanie.

\section{Programy i deklaracje OA}

W 1994 r. Stevan Harnad w internetowym apelu wezwał autorów publikacji naukowych nieprzeznaczonych do celów komercyjnych o archiwizowanie ich w internetowych archiwach. Apel ten, znany również jako „Subversive Proposal", stał się początkiem burzliwej dyskusji w środowiskach naukowców, bibliotekarzy i wydawców. Efektem było powstanie w 1997 r. otwartego repozytorium CogPrints oraz stworzenie oprogramowania GNU Eprints służącego do obsługi otwartych repozytoriów. Jedną z najaktywniejszych grup poszukujących alternatywy dla komercyjnego systemu wydawniczego byli bibliotekarze, dzięki którym w 1997 r. stowarzyszenie Association of Research Libraries (ARL) powołało do życia Scholary Publishing and Academic Resource Coalition (SPARC) - stowarzyszenie bibliotek i organizacji majacych za zadanie opracowanie alternatywnych modeli dystrybucji tekstów naukowych. W 2000 r. rozpoczęło działalność wydawnictwo BioMed Central, które jako pierwsze zaczęło wydawać literaturę $\mathrm{OA}$, będąc jednocześnie komercyjną firmą wydawniczą nastawioną na zysk ${ }^{20}$.

Krokiem milowym w rozwoju inicjatywy był wystosowany w $2001 \mathrm{r}$. przez naukowców List Otwarty do Wydawców Naukowych (Open Letter to Scientific Publishers) ${ }^{21}$, nawołujący do utworzenia publicznej biblioteki internetowej, w której znalazłyby się publikacje z zakresu medycyny i nauk ścisłych. Sygnatariuszami listu było 34 tys. naukowców z całego świata, którzy jednocześnie zo-

${ }^{20}$ Krótka historia. Otwarta Nauka. [online]. [dostęp: 13.10.2009]. Dostępny w World Wide Web: <http://otwartanauka.pl/historia/>.

${ }^{21}$ Public Library of Science: Read the Open Letter. [online]. [dostęp: 23.10.2009]. Dostępny w World Wide Web: <http://www.plos.org/about/letter.html>. 
bowiązali się, iż nie będa publikować ani recenzować artykułów dla czasopism odrzucających model OA. W ten sposób doszło do utworzenia Public Library of Science (PLoS), która była początkowo organizacją promującą i wspierająca ideę OA, a następnie przekształciła się w jednego z największych wydawców literatury naukowej, mogącego obecnie rywalizować z największymi wydawcami komercyjnymi.

Ruch OA ewoluowal wraz z rozwojem Internetu. Inicjatywy podejmowane przez środowiska naukowe i bibliotekarskie z czasem trafiały również do świadomości organizacji międzynarodowych, rządów państw i Komisji Europejskiej. Efektem tego są liczne deklaracje i postanowienia popierające i wspierające inicjatywę OA.

W 2000 r. w Tempe (USA, Arizona) odbyło się spotkanie dwóch stowarzyszeń: Association of American Universities (Stowarzyszenie Uniwersytetów Amerykańskich) i Association of Research Libraries (Stowarzyszenie Bibliotek Naukowych). Owocem ich pracy było opublikowanie tzw. Tempe Principles. Principles for Emerging Systems of Scholarly Publishing ${ }^{22}$, czyli „zasad dla nowopowstających systemów publikowania w nauce". Dwa lata później w Budapeszcie przyjęto Budapest Open Access Initiative ${ }^{23}$ (Budapesztańska Inicjatywa Wolnego Dostępu), która była pierwszą ważną międzynarodową deklaracją zawierającą zbiór zasad i popierającą ruch OA. Powstała ona jako podsumowanie spotkania zorganizowanego przez Open Society Institute (OSI) i zawiera pierwszą definicję Open Access, a także przedstawia strategie i cele dostępu do komunikacji naukowej.

W Budapeszcie zarekomendowano dwie drogi służące uwolnieniu artykułów naukowych. Pierwszą z nich było wydawanie czasopism OA, a drugą autoarchiwizowanie prac naukowych w otwartych repozytoriach. W 2003 r. Howard Hughes Medical Institute (HHMI) oraz Max Planck Society zorganizowały spotkania na temat $O A$ widzianego z perspektywy instytucji finansujących badania naukowe. Wynikiem spotkania zorganizowanego przez HHMI był dokument Bethesda Statement on Open Access Publishing ${ }^{24}$, natomiast podczas konferencji zorganizowanej przez Max Planck Society uchwalono Berlin Declaration on Open Access to Knowledge in the Sciences and Humanities ${ }^{25}$. Obydwie deklaracje zawierają określenia Open Access z naciskiem na rolę instytucji finansujących badania naukowe, wymieniają również warunki publikowania w modelu OA oraz przedstawiają Internet jako narzędzie służące dystrybucji wiedzy. W Bethesda Statement on Open Access Publishing zapisano, że publikowanie prac naukowych jest zasadniczym elementem badań, zaś wyniki badań powinny być powszechnie dostępne i użyteczne w takim stopniu, jak to tylko jest możliwe, tak

${ }^{22}$ Tempe Principles. Principles for Emerging Systems of Scholarly Publishing. [online]. [dostęp: 10.09.2009]. Dostępny w World Wide Web: <http://www.lib.utk.edu/colldev/ tempeprinciples.pdf>.

${ }^{23}$ Budapest Open Access Initiative. [online]. [dostęp: 10.09.2009]. Dostępny w World Wide Web: <http://www. soros.org/openaccess/read.shtml>.

${ }^{24}$ Bethesda Statement on Open Access Publishing. [online]. [dostęp: 10.09.2009]. Dostępny w World Wide Web: <http://www.earlham.edu/ peters/fos/bethesda.htm>.

${ }^{25}$ Berlin Declaration on Open Access to Knowledge in the Sciences and Humanities. [online]. [dostęp: 11.09.2009]. Dostępny w World Wide Web: <http://oa.mpg de/openaccess-berlin/berlin_declaration.pdf> 
aby korzyści płynące z maksymalnego dostępu do informacji mogli czerpać naukowcy, badacze i społeczeństwo.

Brytyjska instytucja Wellcome Trust była pierwszą, która wprowadziła model OA do finansowanych przez siebie badań naukowych. Brytyjskie władze i ustawodawcy również postanowili zwiększyć dostęp do badań naukowych finansowanych ze środków publicznych. W 2004 r. House of Commons Science and Technology Committee zalecił, aby wszystkie szkoły wyższe i grupy badawcze (Research Councils), brytyjskie agencje rzadowe do spraw finansowania rozwoju badań naukowych utworzyły darmowe repozytoria instytucjonalne dostępne online, a jednocześnie wezwał do wsparcia idei czasopism OA. Zalecenie to miało wpływ na wprowadzenie OA przez pięć z ośmiu agencji ds. finansowania rozwoju badań naukowych działających w Wielkiej Brytanii.

W 2006 r. Komisja Europejska zaleciła, aby publikacje naukowe sfinansowane z pieniędzy unijnych były dostępne w archiwach OA. Zaś w sierpniu 2008 r. uruchomiła pilotażowy program OA w ramach 7 Programu Ramowego (7PR). Beneficjenci otrzymujący dofinansowanie w siedmiu obszarach (m.in. energia, zdrowie, nauki humanistyczne i społeczne) zobowiązani zostali do publikowania wynikow badań finansowanych z 7PR w otwartych repozytoriach, najpóźniej po upływie 6 lub 12 miesięcy od daty opublikowania, w zależności od reprezentowanej dziedziny ${ }^{26}$. W dokumencie Open Access Pilot in 7FP Komisja Europejska zaznacza ponadto, że publikowanie wyników badań w wolnym dostępie nie tylko zwiększa widoczność prac naukowych, co prowadzi wprost do wzrostu cytowalności publikacji i ich oddziaływania na naukę, ale również zmniejsza prawdopodobieństwo marnowania czasu i pieniędzy publicznych na dublowanie badań.

W grudniu 2007 r. European Research Council przyjęla ERC Scientific Council Guidelines for Open Access ${ }^{27}$. Wśród wytycznych znajduje się zapis, że wszystkie recenzowane publikacje finansowane przez ERC mają być deponowane w otwartych repozytoriach, takich jak ArXiv czy PubMed Central nie później niż po upływie pół roku od momentu opublikowania.

W Stanach Zjednoczonych przedstawiono projekt ustawy Federal Research Public Access Act ${ }^{28}$, której celem jest wprowadzenie OA do badań finansowanych przez 11 największych instytucji (m.in. National Institutes of Health, Department of Energy, National Science Foundation $)^{29}$. Projekt został przedstawiony przez senatorów Josepha Liebermana i Johna Coryna w czerwcu 2009 r. (pierwszy raz poddany dyskusji w 2006 r.). Również on daje naukowcom, których badania finansowane są przez rząd, 6 miesięcy na opublikowanie postprintów $w$ repozytorium $O A$.

${ }^{26}$ Open Access Pilot in 7FP. [online]. [dostęp: 22.10.2009]. Dostępny w World Wide Web: <ftp://ftp.cordis.europa.eu/pub/fp7/docs/open-access-pilot_en.pdf>.

${ }^{27}$ ERC Scientific Council Guidelines for Open Access. [online]. [dostęp: 22.10.2009]. Dostępny w World Wide Web: <http://erc.europa.eu/pdf/ScC_Guidelines_Open_Access_ revised Dec07 FINAL.pdf>.

${ }^{28}$ Federal Research Public Access Act. [online]. [dostęp: 22.10.2009]. Dostępny w World Wide Web: <http://www.arl.org/sparc/advocacy/frpaa/>.

${ }^{29}$ Open Access w komunikacji naukowej. [w:] elFL-IP Podręcznik prawa autorskiego dla bibliotekarzy. [dostęp: 10.10.2009]. Dostępny w World Wide Web: <http://www.eifl.net/ cps/sections/services/eifl-ip/issues/handbook_p/handbook-p>. 
Amerykański Senat zapowiedział głosowanie nad ustawą wprowadzająca finansowanie dla projektów otwartych podręczników. Projekt ustawy został przedstawiony 24 września 2009 r. przez Dicka Durbina, senatora ze stanu Illinois. Według informacji na oficjalnej stronie senatora ${ }^{30}$ celem nowej ustawy, występującej pod nazwą Open College Textbook Act (Akt Otwartych Podręczników Akademickich), jest przygotowanie konkurencyjnego grantu na finansowanie prac nad otwartymi podręcznikami, które mogą być udostępnione online i na warunkach publicznego dostępu, zapewniają możliwość dostosowania treści do potrzeb odbiorców oraz latwą dystrybucję. Grant jest skierowany do instytucji kształcących, profesorów i organizacji, które chcą włączyć się w inicjatywę wolnych podręczników. Zdaniem Durbina, od 10 lat wydawcy podręczników sztucznie podnoszą ich ceny poprzez uzupełnienia publikowane w wersji online i dodatki na CD-ROM-ach. Według senatora „nadszedł odpowiedni czas, aby wykorzystać potencjał technologii w celu poprawy dostępu do edukacji i wiedzy dla wszystkich studentów". Durbin ma nadzieję, że przyjęcie projektu ustawy ułatwi osiągnięcie tych celów. Według Richa Williamsa, członka stowarzyszenia US PIRG Higher Education, przyjęcie propozycji ustawy to zdecydowany krok w kierunku tańszych podręczników o wysokiej jakości i tym samym łatwiejszego dostępu do edukacji. Otwarte podręczniki to również korzyści dla profesorów, którzy, mając ułatwiony dostęp do sprawdzonych treści, moga podnieść poziom nauczania. Wśród głównych wytycznych wymienianych w Akcie znalazło się zapewnienie, że podręczniki tworzone dzięki federalnym dotacjom będą udostępniane w oparciu o otwarte licencje ${ }^{31}$. Pierwszym stanem, który wprowadził odpowiednie przepisy prawne wspierające otwarty dostęp do materiałów naukowych i edukacyjnych, była Kalifornia. W październiku 2009 r. gubernator Arnold Schwarzenegger podpisal pakiet legislacyjny, który ma wspierać tworzenie cyfrowych podręczników i innych materiałów dla studentów w stanie Kalifornia. Zmiany prawne mają zwiększyć liczbę wolnych podręczników i dostępność do materiałów edukacyjnych ${ }^{32}$.

Kraje rozwijające się i przechodzące transformację ustrojową również zapoczątkowaly inicjatywy propagujące Open Access. Idea OA powoli staje się popularna również w Polsce, choć u nas jest wciąż w początkowej fazie rozwoju. Inicjatywa Open Society Institute (OSI), finansowana ze środków Electronic Information for Libraries ${ }^{33}$, zaowocowała serią warsztatów, które odbyły się w Chinach, Polsce, Serbii, RPA, na Litwie, Ukrainie, w Gruzji oraz Etiopii. W ich wyniku powstały grupy robocze zajmujące się OA, uzyskano również zapewnienie wsparcia tej inicjatywy przez krajowe fundacje zajmujące się badaniami

${ }^{30}$ Durbin Introduces Legislation to Make College Textbooks more Affordable. Thursday. September 24, 2009. [online]. [dostęp: 13.10.2009]. Dostępny w World Wide Web: <http://durbin.senate.gov/showRelease. $\mathrm{cfm}$ ? releaseld $=318279>$

${ }^{31}$ USA: Projekt senackiej ustawy o otwartych podręcznikach. [w:] Koalicja Otwartej Edukacji. [online]. [dostęp: 18.10.2009]. Dostępny w World Wide Web: <http://koed.org.pl/ 2009/10/illinois-projekt-ustawy-w-kierunku-otwartych-podrecznikow/>.

${ }^{32}$ Governor Schwarzenegger Signs Legislation Furthering Digital Textbook Initiative. [w:] Office of the Governor Arnold Schwarzenegger. The People's Governor. [online]. [dostęp: 18.10.2009]. Dostępny w World Wide Web: <http://gov.ca.gov/press-release/13561>

${ }^{33}$ Adres projektu: <http://elFL.net>. 
naukowymi, przygotowano krajowe zalecenia, a także utworzono otwarte repozytoria ${ }^{34}$.

Inicjatywa Open Access jest szczególnie ważna dla rozwoju nauki, zwłaszcza w krajach rozwijających się. Pozwala nie tylko uzyskać dostęp do publikacji, ale również daje możliwość zaistnienia w świecie nauki badaczom z tych krajów.

W 2006 r. południowoafrykańska Akademia Nauk przeprowadziła badania, z których wynikało, że przez ostatnie 14 lat artykuły z jednej trzeciej czasopism naukowych wydawanych w tym kraju nie były ani razu cytowane przez odpowiadajace im czasopisma międzynarodowe. Mimo że RPA jest największym na kontynencie wydawcą publikacji naukowych, mniej niż jedno na dziesięć z 255 akredytowanych czasopism południowoafrykańskich było cytowane w najważniejszych międzynarodowych bazach danych. Świadomość istnienia badań naukowych prowadzonych w RPA czy krajach rozwijających się musi znacząco wzrosnąć, zwłaszcza, że rozwijają się w nich dziedziny, takie jak medycyna czy klimatologia, które wnoszą bardzo wiele do globalnego zasobu wiedzy. Badania te powinny stać się częścią światowej nauki, a może się to stać wlaśnie za sprawą OA. Udowodniono, że artykuły udostępniane w tym modelu drogą elektroniczną były średnio o 50\% częściej cytowane niż artykuły z tego samego czasopisma dostępne w tradycyjnej postaci.

W Salvador Declaration on Open Access: the Developing World Perspective, przyjętej w 2005 r. na międzynarodowym seminarium w Brazylii, stwierdzono, że w świecie, w którym nauka jest powszechna, nie można akceptować wyłączenia z dostępu do informacji naukowej. OA zapewni naukowcom z krajów rozwijających się dostęp do globalnej nauki i umożliwi oddziaływanie na nią, zwiększając znaczenie badań mających bezpośredni wpływ na ich kraje. Konieczność włączenia informacji o badaniach naukowych z krajów rozwijających się do światowej wiedzy znalazła się w zbiorze zasad National Open Access Policy for Developing Countries, uzgodnionym w listopadzie 2006 r. podczas warsztatów zorganizowanych przez Indian Institute of Science, Indian Academy of Sciences oraz the MS Swaminathan Research Foundation. Zwrócono w nim uwagę, że jedyne w swoim rodzaju badania naukowe prowadzone w krajach reprezentujacych $80 \%$ światowej populacji pozostają niewidoczne dla światowej nauki ${ }^{35}$.

\section{Dyskusje wokół OA}

Konsekwencje, jakie ponoszą sami naukowcy w związku z monopolistycznymi praktykami wydawców czasopism, pozostają często nieuświadomione. Dostęp do źródeł, zarówno tradycyjnych, jak i elektronicznych, jest z punktu widzenia użytkowników bibliotek naukowych bezpłatny i nieograniczony. Najnowsze czasopisma, książki, bazy danych bibliograficzne i pełnotekstowe udostępniane są im w bibliotece lub przez sieć instytucjonalną. Ale użytkownicy nie zdają so-

${ }^{34}$ Open Access w komunikacji naukowej. [w:] elFL-IP Podręcznik prawa autorskiego dla bibliotekarzy. [online]. [dostęp: 10.09.2009]. Dostępny w World Wide Web: <http:// www.eifl.net/cps/sections/services/eifl-ip/issues/handbook_p/handbook-p>.

${ }^{35}$ Open Access w komunikacji naukowej. [w:] elFL-IP Podrecznik prawa autorskiego dla bibliotekarzy. [online]. [dostęp: 10.09.2009]. Dostępny w World Wide Web: <http:// www.eifl.net/cps/sections/services/eifl-ip/issues/handbook_p/pol_oa-pdf/downloadFile/ file/file? nocache $=1180334614.97>$. 
bie sprawy z obciążenia, jakie dla budżetu biblioteki stanowi prenumerata i wciąż rosnące koszty dostępu do źródeł prezentujących wyniki badań naukowych. Konsekwencją tego jest ograniczanie prenumeraty, konieczność dokonywania wyboru pomiędzy zakupem kilku równie wartościowych baz danych, czasem rezygnacja z dostępu do źródeł sieciowych ${ }^{36}$. Wciąż jednak ci sami naukowcy, którzy chętnie korzystają z dorobku innych i chętnie publikują w komercyjnych bazach danych, nie wyrażają woli udostępniania własnej twórczości w ramach otwartych czasopism lub repozytoriów.

Jednym z przytoczonych już wcześniej argumentów, który powinien przekonać naukowców do włączenia własnej twórczości do repozytorium OA, jest niemalże natychmiastowe publikowanie prac naukowych oraz szersze pole oddziaływania. Publikacja dostępna w wolnym dostępie jest częściej przytaczana również w cytowaniach. Zwiększenie cytowalności pracy w zależności od dziedziny wynosi od $36 \%$ do $172 \%{ }^{37}$, a nawet $250 \%$ dla artykułów z fizyki ${ }^{38}$.

Istotnym problemem może się jednak okazać kwestia zaliczenia publikacji udostępnianych w wolnym dostępie do dorobku naukowego. Najlepszym obecnie rozwiązaniem wydaje się być publikowanie w ramach OA dzieł wcześniej wydanych w formie tradycyjnej oraz archiwizowanie w repozytoriach recenzowanych postprintów, gdyż do dorobku naukowego wliczane są głównie te prace, które wydane zostały w czasopismach recenzowanych, ujętych na listach czasopism punktowanych. Z czasem być może otwarte repozytoria i czasopisma OA staną się w większym stopniu postrzegane jako równie wartościowe w oczach decydentów. Aby tak się stało, muszą być nadal rozwijane mechanizmy oceny i weryfikacji jakości prac Obiecującym w tej materii jest fakt, że „BMC Medical Genomics", jedno z czasopism wydawanych przez BioMed Central, od czerwca 2010 roku otrzyma swój pierwszy Impact Factor ${ }^{39}$.

Rozważając problem uwolnienia publikacji naukowych komercyjnych wydawców, należy wziąć pod uwagę dwa pojawiające się zasadnicze problemy: finansowanie i gwarancję jakości udostępnianych opracowań.

Rozwój i jakość otwartych repozytoriów zależy nie tylko od społecznej inicjatywy autorów i twórców repozytoriów, ale w dużej mierze również od źródeł finansowania. Zależnie od typu repozytorium może być finansowane przez pojedynczą instytucję, przez konsorcjum, państwo lub przy wykorzystaniu funduszy unijnych ${ }^{40}$. Różne opinie na temat tego, kto powinien finansować publikowanie

${ }^{36}$ Niedźwiedzka B., op. cit.

${ }^{37}$ Hajjem CH.: Ten-Year Cross-Disciplinary Comparison of the Growth of Open Access and How it Increases Research Citation Impact. "IEEE Data Engineering Bulletin" 2005, nr 28(4), s. 39-47. [online]. [dostęp: 14.09.2009]. Dostępny w World Wide Web: <http:// eprints.ecs.soton.ac.uk/12906/>

${ }^{38}$ Brody T. D.: Evaluating research impact through Open Access to scholarly communication. PhD thesis University of Sauthampton 2006. [online]. [dostęp: 14.09.2009]. Dostępny w World Wide Web: <http://eprints.ecs.soton.ac.uk/13313/1/brody.pdf>.

${ }^{39}$ BMC Medical Genomics to receive its first Impact factor in June 2010. [w:] BioMed Central Blog. [online]. [dostęp: 13.10.2009]. Dostępny w World Wide Web: <http://blogs.openaccesscentral.com/blogs/bmcblog/entry/bmc_medical_genomics_to_receive>.

${ }^{40}$ Bednarek-Michalska B.: Fundusze na budowanie zasobów elektronicznych w Polsce. [w:] III Konferencja - Internet w bibliotekach. Zasoby elektroniczne: podaź i popyt. [online]. [dostęp: 13.09.2009]. Dostępny w World Wide Web: <http://www.ebib.info/publikacje/matkonf/iwb3/artykul.php?b>. 
dzieł w otwartym dostępie, mają również sami zwolennicy inicjatywy OA. Jeden $z$ projektów mówi, że to autor (lub jego macierzysta instytucja) powinien sfinansować publikowanie własnego dzieła, na przykład ze środków przekazanych mu na badania w ramach grantu, inne obarczaja odpowiedzialnością za proces wydawniczy biblioteki i instytucje naukowe. Ogólnym przesłaniem jest wyłączenie z tego procesu komercyjnych wydawców. O ile jeszcze biblioteki i instytucje mogłyby w ramach swojej działalności uruchomić proces wydawniczy, o tyle mało prawdopodobna, zwłaszcza w warunkach polskich, wydaje się akceptacja naukowców dla pomysłu, aby to oni finansowali wydawanie własnych publikacji. Proces wydawniczy jest dość rozbudowany i wymagałby wysokiego poziomu dyscypliny zarówno samych autorów, jak i recenzentów. Mimo to w wielu krajach z powodzeniem funkcjonuje model tzw. autoarchiwizacji (ang. self-archiving), polegający na tym, że to sami autorzy, jako zalogowani użytkownicy, przesyłają prace na serwer repozytorium. Cały proces recenzowania i następnie upowszechniania również odbywa się online ${ }^{41}$, co znacznie przyspiesza tempo umieszczania prac w repozytorium, recenzowania i publikowania.

Drugi problem dotyczy jakości publikacji prezentowanych w wolnym dostępie. Autorzy prac naukowych nie mogą się obejść bez niezależnych recenzji, gwarancji jakości i wskaźników wpływu, dlatego jedną z propozycji jest współpraca z tradycyjnymi redakcjami czasopism, których rola ograniczałaby się do pośredniczenia w uzyskiwaniu wysokiej klasy recenzji, za która to usługę oraz za udostępnienie własnego szyldu (tytułu czasopisma) pobierałyby opłaty. Mówi się, że i tu środowisko naukowe mogłoby się odpowiednio zorganizować, zapewniając sobie recenzje i gwarantując jakość publikowanych źródeł nazwą instytucji, towarzystwa naukowego lub uczelni. Czy jest to wykonalne, okaże się w przyszłości ${ }^{42}$.

Chociaż OA ma tak wiele zalet i korzyści, autorzy sceptycznie odnoszą się do publikowania swojej twórczości w Internecie. Najwięcej obaw budzi kwestia respektowania praw autorskich przez użytkowników otwartych repozytoriów ${ }^{43}$. W świetle Ustawy o Prawie Autorskim i Prawach Pokrewnych twórcy przysługuje pełne prawo do zachowania własności i jej ochrony. Wszelkie naruszenia ujętych w niej zapisów są traktowane jako niezgodne z prawem i podlegają odpowiednim restrykcjom. Często wśród sceptyków panuje opinia, jakoby udostępnienie swojego dzieła w wolnym dostępie ułatwiało kradzież intelektualna, plagiat i niewłaściwe wykorzystanie dzieła. Jednakże patrząc na tę kwestię, łatwo zauważyć, że, paradoksalnie, utwory powszechnie dostępne trudniej jest splagiatować w sposób niezauważony.

Przepisy prawa autorskiego mogą być przeszkodą w publikowaniu utworów w wolnym dostępie. Prawa autorskie do artykułów w czasopismach naukowych,

${ }^{41}$ Eriksson J.: Tworzenie archiwum instytucji - kwestie techniczne i organizacyjne (Setting up an institutional archive: some technical and organisational considerations). [w:] IV Ogólnopolska Konferencja EBIB - Internet w bibliotekach. Open Access. [online]. [dostęp: 12.09.2009]. Dostępny w World Wide Web: <http://www.ebib.info/publikacje/matkonf/ mat18/eriksson.php>.

${ }^{42}$ Niedźwiedzka B., op. cit.

${ }^{43}$ Stanislawska-Kloc S.: Prawa autorskie a biblioteka cyfrowa - opinia prawna sporządzona w ramach projektu KPBC finansowanego z Funduszy Strukturalnych UE. „Biuletyn EBIB" 2005, nr 9 (70). [online]. [dostęp: 15.09.2009]. Dostępny w World Wide Web: <http:// ebib.oss.wroc.pl/2005/70/stanislawska-kloc.php>. 
książek oraz ich fragmentów, w ramach umowy wydawniczej z autorem, przechodzą często na wydawców, co pozbawia autora możliwości dysponowania dziełem, w tym również udostępniania go w sieci bez zgody wydawcy. Z umowy autorskiej mogą wynikać również inne ograniczenia, na przykłảd dotyczące rozpowszechniania preprintów i postprintów ${ }^{44}$.

Prawo autorskie jest zasadniczym problemem dla osób tworzących cyfrowe repozytoria. W odpowiedzi na ograniczenia i kłopoty z prawem autorskim powstała wspomniana już inicjatywa Creative Commons (CC). Creative Commons oferuje twórcom licencje, które pozwalają im zachować własne prawa i jednocześnie dzielić się swoją twórczością z innymi. Licencje CC działają na zasadzie „pewne prawa zastrzeżone" - granice dozwolonego użytku są szersze i wyrażniejsze niż te wytyczone na zasadzie „wszelkie prawa zastrzeżone”. Głównym przesłaniem jest poszanowanie prawa twórców do dokonywania wyboru stopnia, w jakim chcą się dzielić swoją twórczością z innymi. Wszystkie licencje i narzędzia CC są dostępne za darmo. Do zadań CC należy też edukacja prawnicza - zwiększenie świadomości wpływu systemu własności intelektualnej na kulturę i społeczeństwo oraz zwiększenie zrozumienia i poszanowania dla prawa i cudzej twórczości ${ }^{45}$.

W Polsce, podobnie jak i na świecie, mamy do czynienia z dwiema postawami wobec tworzenia dostępu do wiedzy: postawą otwartą, zakładająca, zgodnie z Powszechną Deklaracją Praw Człowieka, że każdy ma prawo do nieograniczonego dostępu do informacji i wiedzy, oraz z postawą zamknięta, gdzie pojawia się twierdzenie, iż tworzenie zasobów wiedzy jest kosztowne, zatem za dostęp do wyników działalności naukowej należy płacić. Jednak największe światowe organizacje bibliotekarskie, takie jak IFLA czy ALA, zalecają postawę otwartą, zwłaszcza w bibliotekach ${ }^{46}$. W Deklaracji w sprawie Bibliotek, Ośrodków Informacji i Wolności Intelektualnej sporządzonej w Glasgow w 2002 r., a także w Stanowisku IFLA w sprawie Open Access z 2003 r. Międzynarodowa Federacja Stowarzyszeń i Instytucji Bibliotekarzy potwierdza, że wszechstronny, otwarty dostęp do literatury naukowej i dokumentacji badań naukowych jest niezbędny dla zmniejszenia nierówności w dostępie do informacji i jest gwarancją dla nienaruszalności komunikacji naukoweje ${ }^{47}$.

Warto przytoczyć podstawowe zarzuty i argumenty przywoływane przeciwko inicjatywie OA. Pierwszy z nich wiąże się z finansami - ponieważ wiele czasopism naukowych wydają uczelnie oraz towarzystwa naukowe, dochody $z$ ich sprzedaży służą upowszechnianiu nauki, a rezygnacja z dochodów z czasopism pozba-

\footnotetext{
${ }^{44}$ Kaczmarek E., Rychlik M., op. cit.

${ }^{45}$ Więcej na stronie internetowej Creative Commons Polska: <http://creativecommons.pl> Zob. też: J. Hofmokl, A. Tarkowski: Creative Commons, innowacje w systemie prawa autorskiego i rozwój wolnej kultury. „Biuletyn EBIB” 2005, nr 3 (64). [online]. [dostęp: 15.09.2009]. Dostępny w World Wide Web: <http://ebib.oss.wroc.pl/2005/64/hofmokl_tarkowski.php>.

${ }^{46}$ Bednarek-Michalska B.: Wolny dostep do informacji i wiedzy czy wykluczenie edukacyjne? Trendy światowe a Polska. „Biuletyn EBIB” 2005, nr 2 (63). [online]. [dostęp: 08.09. 2009]. Dostępny w World Wide Web: <http://ebib.oss.wroc.pl/2005/63/michalska.php>.

${ }^{47}$ Deklaracja w sprawie Bibliotek, Ośrodków Informacji i Wolności Intelektualnej sporządzona w Glasgow. [online]. [dostęp: 08.09.2009]. Dostępny w World Wide Web: http:/l ebib.oss.wroc. pl/2005/63/glasgow.php; Stanowisko IFLA w sprawie Open Access. [online]. [dostęp: 08.09.2009]. Dostępny w World Wide Web: <http://ebib.oss.wroc.pl/2005/63/ ifla.php>.
} 
wia je środków na inne sfery działalności. Istnieją również obawy, że zmiany mogą niebezpiecznie zaburzyć porządek towarzyszący upowszechnianiu wiedzy, a ustabilizowana przez wieki renoma i ranking czasopism mogą zostać zniszczone. Rozchwianiu moga ulec również wskaźniki wiarygodności oraz jakości recenzji. Pojawia się również pytanie, czy w wyniku zlikwidowania barier w publikowaniu nie obniży się jakość samych publikacji naukowych. Przeciwnicy OA twierdzą także, że obarczanie autorów opłatami za publikowanie własnych dzieł może spowodować jeszcze większe niż dotąd nierówności, ponieważ uprzywilejowani będa pracownicy większych instytucji, dysponujących większymi środkami oraz właściciele większych grantów. Jeśli z grantów będą opłacane koszty publikowania, naukowcy będą mieli mniej pieniędzy na same badania, a opłaty za recenzje mogą być wysokie, a nawet specjalnie zawyżane przez czasopisma o wysokiej renomie. Sceptycy zadają również pytanie, czy w ogóle $w$ interesie środowiska naukowego leży bezpłatne udostępnianie wyników badań przemysłowi i komercji. Wszystkie te pytania nie są bezzasadne, ale wydaje się, że nie powinny negować samej inicjatywy OA, a raczej spowodować dokładniejsze, ostrożniejsze i bardziej przemyślane planowanie działań, precyzyjną kalkulację kosztów i przemyślaną organizację nowego modelu komunikacji naukowej tak, by była korzystna zarówno dla nauki i naukowców, jak i odbiorców informacji naukowej takich jak użytkownicy bibliotek ${ }^{48}$.

Argumentów za postawą otwartą jest wiele, ale koronnym argumentem jest walka $z$ wykluczeniem informacyjnym oraz fakt, że koszty wytworzenia zasobów wiedzy ponoszą wszyscy podatnicy. Skoro przy powszechnej globalizacji informacja jest traktowana jako najważniejszy element rozwoju cywilizacyjnego, to ograniczenia w dostępie do niej tworzą sferę wykluczonych, których nie stać na jej zakup.

\section{Popularyzacja OA}

W ostatnich latach tematyka OA cieszy się coraz większą popularnością i chociaż brak jeszcze w Polsce całościowego jej opracowania, to poszczególne aspekty OA doczekały się omówienia. Wśród polskich autorów poruszających kwestie idei OA jako nowego modelu komunikacji naukowej należy wymienić Marka Niezgódkę, Andrzeja Górskiego, Bożenę Bednarek-Michalską czy Lidię Derfert-Wolf. O Open Acces pisali również m.in.: Aneta Januszko Szakiel, Maciej Banach, Małgorzata Kowalska, Agnieszka Łozowska, Bogusława Macheta, Paweł Najserek, Jolanta Stępniak, Emilia Kaczmarek, Małgorzata Rychlik, o czasopismach udostępnianych w otwartym dostępie napisali Łucja Maciejewska, Krzysztof Moskwa i Barbara Urbańczyk, natomiast o publikowaniu i bazach OA z dziedziny medycyny Barbara Niedźwiedzka i Jolanta Przyłuska. Kwestie prawne dotyczące udostępniania twórczości w wolnym dostępie porusza Barbara Szczepańska, o licencjach CC piszą obszernie Alek Tarkowski oraz Joanna Hofmokl. W celu bardziej szczegółowego zgłębienia tej tematyki należy jednak sięgnąc do literatury zagranicznej. O miejscu modelu OA w komunikacji nauko-

${ }^{48}$ Niedźwiedzka B.: Open Access cz.ll. Upowszechnianie wyników badań naukowych w sieci. "Forum Akademickie" 2005, nr 5, s. 38-40. 
wej w Wielkiej Brytanii pisze w artykułach i wystapieniach konferencyjnych Frederick Friend, zaś o wpływie otwartego modelu na poziom cytowań oraz oddziaływanie w nauce Stevan Harnad, Chawki Hajjem, Kayvan Kousha oraz Mahshid Abdoli (w Polsce Marek Nahotko). Prekursorami ruchu propagującego otwarty dostęp do wyników badań naukowych i zarazem najlepiej opisującymi tę tematykę są: Charles Oppenheim, Peter Suber czy Jean-Claude Guédon. Wśród zagranicznych są również tacy autorzy, którzy specjalizują się w określonej części zagadnień dotyczących $O A$, a więc w zagadnieniach technicznych, prawnych, źródłach finansowania, pokonywaniu barier świadomościowych i legislacyjnych, opisywaniu doświadczeń na polu wdrażania inicjatywy w poszczególnych krajach. Możemy znaleźć również sprawozdania różnych organizacji zajmujących się promowaniem i wdrażaniem otwartego modelu, takich jak Max Planck Society, opisy projektów, takich jak E-LIS, DOAJ, czy RoMEO. Pomocne w badaniach nad rozwojem OA w Polsce i na świecie są również przepisy prawne, deklaracje oraz informacje publikowane przez wyższe uczelnie, instytucje i organizacje, które wprowadzają model OA do swojej działalności. Wśród nich możemy wyróżnić Europejską Organizację Badań Jądrowych (CERN), Uniwersytet Harvarda, Uniwersytet Kalifornijski, konsorcjum uniwersytetów włoskich - Consorzio Interuniversitario Lombardo per l'Elaborazione Automatica (CILEA) czy austriacki fundusz na rzecz wspierania badań naukowych - Fonds zur Förderung der wissenschaftlichen Forschung (FWF).

W nurcie OA powstają również różnego typu inicjatywy: blogi, portale społecznościowe oraz inne witryny internetowe, które swoją działalnością propagują OA na gruncie polskim, (blog Otwarta Nauka, strona Koalicji Otwartej Edukacji, Creative Commons Polska czy też blog i forum Biblioteka 2.0). Odbywają się też liczne konferencje i warsztaty mające upowszechnić wiedzę na temat OA, na przykład kursy Laboratorium Indeksu 73, Creative Commons Polska, konferencje EBIB z cyklu Open Access czy też konferencje i warsztaty Polskiej Akademii Nauk, działającej na gruncie międzynarodowym.

Międzynarodowe organizacje Scholarly Publishing and Academic Resources Coalition (SPARC), Students for FreeCulture, and the Public Library of Science ustanowiły 14 października 2008 r. Dniem Open Access ${ }^{49}$, a w dniach 19-23 października 2009 r. odbył się, ogłoszony po raz pierwszy, międzynarodowy Tydzień Open Access ${ }^{50}$. W ramach tej inicjatywy odbyły się warształy i konferencje oraz przeprowadzona została międzynarodowa kampania propagująca ideę wolnego dostępu.

O wadze i aktualności tej tematyki świadczy również fakt, że kongres IFLA w 2010 r. będzie poświęcony właśnie Open Access.

Najważniejszym zadaniem entuzjastów OA jest szerokie propagowanie tej idei wśród naukowców i wydawców oraz działalność edukacyjna mająca na celu przedstawienie korzyści płynących z nowego modelu komunikacji naukowej zarówno dla środowiska naukowego, jak i całego społeczeństwa.

${ }^{49}$ Open Access Day. [w:] Otwarta Nauka. [online]. [dostęp: 08.09.2009]. Dostępny w World Wide Web: <http://otwartanauka.pl/blog/2008/10/open-access-day/>

${ }^{50}$ Open Access Week - October 19-23.2009. To broaden awareness and understanding of Open Access. [online]. [dostęp: 22.10.2009]. Dostępny w World Wide Web: <http:/l www.openaccessweek.org/> 


\section{Bibliografia}

1. Bednarek-Michalska Bożena: Fundusze na budowanie zasobów elektronicznych w Polsce. [W:] III Konferencja - Internet w bibliotekach. Zasoby elektroniczne: podaż i popyt. [online]. [dostęp: 13.09.2009]. Dostępny w World Wide Web: <http://www.ebib. info/publikacje/matkonf/iwb3/artykul.php?b>.

2. Bednarek-Michalska Bożena: Wolny dostęp do informacji i wiedzy czy wykluczenie edukacyjne? Trendy światowe a Polska. „Biuletyn EBIB” 2005, nr 2 (63). [online]. [dostęp: 10.09.2009]. Dostępny w World Wide Web: <http://ebib.oss.wroc.pl/2005/63/michalska.php>.

3. Berlin Declaration on Open Access to Knowledge in the Sciences and Humanities. [online]. [dostęp: 10.09.2009]. Dostępny w World Wide Web: <http://oa.mpg.de/openaccess-berlin/berlin declaration.pdf>.

4. Bethesda Statement on Open Access Publishing. [online].[dostęp: 10.09.2009]. Dostępny w World Wide Web: <http://www.earlham.edu/ peters/fos/bethesda.htm>.

5. BMC Medical Genomics to receive its first Impact factor in June 2010. [w:] BioMed Central Blog. [online]. [dostęp: 13.10.2009]. Dostępny w World Wide Web: <http://blogs.openaccesscentral.com/blogs/bmcblog/entry/bmc_medical_genomics_to_receive >.

6. Brody Timothy David: Evaluating research impact through Open Access to scholarly communication, PhD thesis University of Sauthampton 2006. [online]. [dostęp: 14.09.2009]. Dostępny w World Wide Web: <http://eprints.ecs.soton.ac.uk/13313/1/brody. pdf>.

7. Budapest Open Access Initiative. [online]. [dostęp: 10.09.2009]. Dostępny w World Wide Web: <http://www.soros.org/openaccess/read.shtml>.

8. Deklaracja w sprawie Bibliotek, Ośrodków Informacji i Wolności Intelektualnej sporządzona w Glasgow. [online]. [dostęp: 08.09.2009]. Dostępny w World Wide Web: <http:// ebib.oss.wroc.pl/2005/63/glasgow.php>.

9. DOAJ - Directory of Open Access Journals. [online]. [dostęp: 10.09.2009]. Dostępny w World Wide Web: <http://www.doaj.org/>.

10. Durbin Introduces Legislation to Make College Textbooks more Affordable, Thursday, September 24, 2009. [online]. [dostęp: 13.10.2009]. Dostępny w World Wide Web: <http://durbin.senate.gov/showRelease.cfm?releaseld=318279>

11. elFL-IP Podręcznik prawa autorskiego dla bibliotekarzy. [online]. [dostęp: 10.09.2009]. Dostępny w World Wide Web: <http://www.eifl.net/cps/sections/services/eifl-ip/issues/ handbook_p/handbook-p>.

12. ERC Scientific Council Guidelines for Open Access. [online]. [dostęp: 22.10.2009]. Dostępny w World Wide Web: <http://erc.europa.eu/pdf/ScC_Guidelines_Open_Access_revised_Dec07_FINAL.pdf>.

13. Eriksson Jörgen: Tworzenie archiwum instytucji - kwestie techniczne i organizacyjne (Setting up an institutional archive: some technical and organisational considerations). [W:] IV Ogólnopolska Konferencja EBIB - Internet w bibliotekach. Open Access. [online]. [dostęp: 12.09.2009]. Dostępny w World Wide Web: <http://www.ebib.info/publikacje/matkonf/mat18/eriksson.php>.

14. Federal Research Public Access Act. [online]. [dostęp: 22.10.2009]. Dostępny w World Wide Web: <http://www.arl.org/sparc/advocacy/frpaa/>.

15. Governor Schwarzenegger Signs Legislation Furthering Digital Textbook Initiative. [W:] Office of the Governor Arnold Schwarzenegger. The People's Governor. [online]. [dostęp: 18.10.2009]. Dostępny w World Wide Web: <http://gov.ca.gov/press-releasel $13561>$

16. Hajjem Chawki: Ten-Year Cross-Disciplinary Comparison of the Growth of Open Access and How it Increases Research Citation Impact. „IEEE Data Engineering Bulletin” 2005, nr 28 (4), s. 39-47. [online]. [dostęp: 14.09.2009]. Dostępny w World Wide Web: $<$ http://eprints.ecs. soton.ac.uk/12906/>.

17. Hofmokl Joanna, Tarkowski Alek: Creative Commons, innowacje w systemie prawa autorskiego i rozwój wolnej kultury. „Biuletyn EBIB” 2005, nr 3 (64). [online]. [dostęp: 15.09.2009]. Dostępny w World Wide Web: <http://ebib.oss.wroc.pl/2005/64/hofmokl_ tarkowski.php>. 
18. Kaczmarek Emilia, Rychlik Małgorzata: Czy repozytoria będą wspierać naukę w Polsce?, Logistyka” 2007, nr 4, s. 93-97.

19. Krótka historia. Otwarta Nauka. [online]. [dostęp: 13.10.2009]. Dostępny w World Wide Web: <http://otwartanauka.pl/historia/>

20. Lessing Lawrence: Wolna kultura. [online]. [dostęp: 10.09.2009]. Dostępny w World Wide Web: <http://www.futrega.org/wk/>.

21. Nahotko Marek: Wpływ Open Access na poziom cytowań publikacji. [W:] IV Ogólnopolska Konferencja EBIB Internet w bibliotekach. Open Access. [online]. [dostęp 11.04. 2008]. Dostępny w World Wide Web: <http://www.ebib.info/publikacje/matkonf/mat18/ nahotko.php>.

22. Niedźwiedzka Barbara: Open Access cz.1. „Forum Akademickie” 2005, nr 4. [online]. [dostęp: 10.09.2009]. Dostępny w World Wide Web: <http://forumakad.pl/archiwum/ 2005/04/17-za-open_acces_cz_1.htm>.

23. Niedźwiedzka Barbara: Opeñ Access, cz. 2. Upowszechnianie wyników badań naukowych w sieci. "Forum Akademickie" 2005, nr 5, s. 38-40.

24. Open Access Day. [W:] Otwarta Nauka. [online]. [dostęp: 08.09.2009]. Dostępny w World Wide Web: <http://otwartanauka.pl/blog/2008/10/open-access-day/>.

25. Open Access Pilot in 7FP [online]. [dostęp: 22.10.2009]. Dostępny w World Wide Web: <ftp://ftp.cordis.europa.eu/pub/fp7/docs/open-access-pilot en.pdf>.

26. Open Access Week - October 19-23, 2009. To broaden awareness and understanding of Open Access. [online]. [dostęp: 22.10.2009]. Dostępny w World Wide Web: <http:// www.openaccessweek.org/>.

27. Open Access w komunikacji naukowej. [W:] elFL-IP Podręcznik prawa autorskiego dla bibliotekarzy. [online]. [dostęp: 10.10.2009]. Dostępny w World Wide Web: <http:/l www.eifl.net/cps/sections/services/eifl-ip/issues/handbook_p/handbook-p>

28. Open Access: Profile of Eberhard Hilf. [W:] Open and shut? Blog of Richard Poynder. [online]. [dostęp: 10.10.2009]. Dostępny w World Wide Web: <http://poynder. blogspot. $\mathrm{com} / \mathrm{s}$

29. Public Library of Science: Read the Open Letter. [online]. [dostęp: 23.10.2009]. Dostępny w World Wide Web: <http://www.plos.org/about/letter.html>.

30. Stanisławska-Kloc Sybilla: Prawa autorskie a biblioteka cyfrowa - opinia prawna sporzadzona w ramach projektu KPBC finansowanego z Funduszy Strukturalnych UE. "Biuletyn EBIB" 2005, nr 9 (70). [online]. [dostęp: 15.09.2009]. Dostępny w World Wide Web: <http://ebib.oss.wroc.pl/2005/70/stanislawska-kloc.php>.

31. Stanowisko IFLA w sprawie Open Access. [online]. [dostęp: 08.09.2009]. Dostępny w World Wide Web: <http://ebib.oss.wroc.pl/2005/63/ifla.php>.

32. Tempe Principles. Principles for Emerging Systems of Scholarly Publishing. [online]. [dostęp: 10.09.2009]. Dostępny w World Wide Web: <http://www.lib.utk.edu/colldev/ tempeprinciples.pdf>.

33. USA: Projekt senackiej ustawy o otwartych podręcznikach. [W:] Koalicja Otwartej Edukacji. [online]. [dostęp: 18.10.2009]. Dostępny w World Wide Web: <http://koed.org.pl/ 2009/10/illinois-projekt-ustawy-w-kierunku-otwartych-podrecznikow/>.

\section{Summary}

The article presents history and modern solutions of the new model of accessing research evidence - i.e. the open access (OA). Selected foreign and Polish activities being realized so far has been compared. Programs, declarations, as well as financial problems, quality of published materials, and OA popularization are discussed. 